\title{
Impact of Microfinance on Rural Transformation in Nigeria
}

\author{
Nwankwo, Odi. ${ }^{1}$, Olukotu, G. A. ${ }^{1}$, \& Abah, Emmanuel ${ }^{1}$ \\ ${ }^{1}$ Department of Banking and Finance, Kogi State University, Chartered Institute of Bankers of Nigeria (CIBN), \\ Anyigba, Nigeria \\ Correspondence: Nwankwo, Odi., Department of Banking and Finance, Kogi State University, Chartered \\ Institute of Bankers of Nigeria (CIBN), Anyigba, Nigeria. Tel: 234-803-576-3229. E-mail: \\ Odinwankwo2002@yahoo.com
}

Received: May 29, 2013

Accepted: July 3, 2013

Online Published: September 18, 2013

doi:10.5539/ijbm.v8n19p99

URL: http://dx.doi.org/10.5539/ijbm.v8n19p99

\begin{abstract}
The introduction of microfinance banks in Nigeria is the inability of Nigerian Deposit Money Banks to provide sufficient financial service to the rural poor. Microfinance banks have taken up the challenges of the gap created by the Nigerian Deposit Money Banks. Microfinance banks can be seen as an economic growth method intended to advantage the low income part of a given country like Nigeria, both rural poor and urban poor. The objective of this study is to determine the impact of microfinance on rural transformation in Nigeria. The methodology used by the researcher was descriptive research. The findings of the study shows that micro-finance has impacted positively on the rural poor by providing loans and advances for agriculture, investment opportunities, savings mobilization and credit delivery; asset financing and community development financing. Despite the achievements of microfinance in transforming the rural areas they have been met with stiff difficulties like repayment problem, illiteracy among the poor and inadequate or non-monitoring of micro and small enterprises by the micro financial institutions. The following recommendations were made to address the issues: To match products to customer needs, examination of cash flows and repayment cycles, broaden the range of products and services to the poor and regulatory authorities should look closer to the activities of the microfinance banks.
\end{abstract}

Keywords: microfinance, rural transformation, rural poor, regulation and urban poor

\section{Introduction}

The introduction of microfinance banks in Nigeria is the inability of Nigerian Deposit Money Banks to provide sufficient financial service to the rural poor. Microfinance banks have taken up the challenges of the gap created by the Nigerian Deposit Money Banks. Microfinance banks can be seen as an economic growth method intended to advantage the low income part of a given country like Nigeria, both rural poor and urban poor.

Again, Robinson (2001) stated that microfinance is a supplier of loans and other financial services to the rural poor. Microfinance bank is the economic growth method with the purpose of advantageous of the male and female rural and urban poor in the country like Nigeria. Microfinance banks are institutions that are established to provide financial services to the poor. Microfinance institutions can be non-governmental organisations, savings and loan cooperatives, loan unions, government banks, commercial banks or non-bank financial institutions (Ledgerwood, 1999; World Bank, 2007). It seeks to make financial services available on a sustainable basis to the economically active poor, low-income earners and micro, small and medium enterprises through privately owned enterprises.

Three features distinguish microfinance from other formal financial products. The features are the low size of loan, not collateral and easy in operation (Ogbunaka, 2003). In both developed and developing countries, microfinance banks have been the strategy for poverty alleviation and human empowerment. In recent years, micro enterprises are using microfinance banks or institutions for an easy way of financial services. Microfinance banks are being used in every country now to achieve Millennium Development Goals (MDGs). Availability of Sustainable financial services helps owners of micro enterprises to grow, finance income, accumulate assets and reduce their vulnerability to external shocks. Access to financial services enable poor households to transform from everyday for survival to planning for the future, investing in better nutrition, their children's welfare and empowering women economically and socially (Ehigiamusoe, 2005). Oter (1999) defined 
microfinance bank as an institution that is not meant to provide capital to the poor which will in turn reduce poverty but the institution that provide fund to the poor both in urban and rural areas who have no access to capital from the deposit money banks or formal banks.

In recent time, some researchers on micro financing have investigated whether micro credit programs that are popular in Nigeria has reached the relatively poor in the urban and rural areas of the country. Some of the researchers have shown that there is significant positive impact of microfinance on micro credit programme as it relates to first six out of seven Millennium Development Goals (Adamu, 2007; Irobi, 2008; Aman, 2000; \& McCulloch \& Baulch, 2000). This means that microfinance bank is an effective and powerful tool for poverty reduction in any country. Amin, Rai \& Topai (2003) confirmed that microfinance has served people below and above the poverty line. Microfinance is not a new financial service In Nigeria as shown by such cultural economic activities as "Esusu", "Adashi", "Otataje", etc, which was practiced with the purpose of providing funds for producers in our rural communities. What is current however is the effort of the government at all level in Nigeria to transform micro-financing in rural and urban communities, to improve the productivity level of rural and urban poor and enhance their economic standing which in the long run increases the level of gross domestic product (GDP). Asian Development Bank (2000) went further to say that microfinance is the provision of a broad range of financial services such as deposits, loans, payment services, money transfers and insurance to poor and low income households, and their micro enterprises.

The main objective of this study is to determine the impact of micro- finance on rural transformation in Nigeria, which the specific objective includes; to examine the role of microfinance institution in rural transformation; to ascertain the level of microfinance operation in Nigeria; and to suggest for the future realization of the microfinance scheme in Nigeria. To assess the effectiveness of microfinance on rural transformation in Nigeria, the following research questions were addressed in this study and shall form the basis of our analysis. First, what significant effect has microfinance bank had on rural transformation in Nigeria?

Secondly, what extend does the poor have access to microfinance funds in Nigeria?

Thirdly, are there any prospects of microfinance in rural transformation banks on rural transformation? And does rural transformation has any effect on the sustainable growth in rural areas of Nigeria?

The scope of this study focuses on the impact of loan size, interest rate on loan and loan repayment rate on the human empowerment in Ebonyi state. Financial institutions like banks play very important role of financial intermediation between the surplus and the deficit units of the economy. By this, banks are able to mobilize savings from the surplus unit for onward lending to the deficit unit of the economy. With these, there is increase in savings and investments which may eventually result to enhancement in the standard of living of the people (Anyanwaokoro, 1996; Nwankwo, 2009). Unfortunately, those in the poverty circle, both in the urban and rural areas are yet to benefit from the activities of conventional banks, and this accounts for persistent high rate of poverty among the populace which call for the introduction of microfinance bank. If in spite of government programs and policies in terms of stable microfinance banks, the level of poverty is still high, there is then the doubt whether micro finance is an effective tool for human financial empowerment in Nigeria. This is the problem this research attempts to address.

\section{Conceptual and Theoritical Framework}

Majority of Nigerian population reside in the rural areas and the poverty level in the economy is about $80 \%$ (Eze, 2011). This compelled the Federal Government of Nigeria to initiate series of publicly micro-financed programmes targeted at the rural and urban poor. Such programmes included Rural Banking Programme, the Nigerian Agricultural and Cooperative Bank (NACB), Peoples Bank of Nigeria, Community Banks, Nigerian Agricultural Insurance Corporation, the Family Economic Advancement Programme, National Poverty Eradication Programme (NAPEP) (CBN, 2005).

The rural bank scheme started in 1977 under the supervision of the Central Bank of Nigeria (CBN). The mechanics of the scheme mandated commercial banks to extend their branch network to various rural areas in order to provide adequate financial services in their areas. The numerical target of at least one branch in every local government area was met by the year 1991 and prior to the termination of the programme; over 700 rural branches were opened nationwide (Aligu, 2003). However, the mainstream commercial banks failed to meet the credit needs of the people, by mobilizing their deposits without granting credit facilities to most depositors. Most of the funds generated from the rural branches were channelled to meet the needs of the customers of branches located in the urban commercial cities. Thus, little or no impact was made in the lives of the rural residents. In 1986, the Central Bank of Nigeria deregulated the banking industry following the Structural Adjustment Programme (SAP), some of the loss making branches in the rural areas were shut down while others 
remained cash centres. The failure of the rural banking led to the establishment of the Peoples Bank of Nigeria, by the Federal Government in 1988. The People's Bank of Nigeria was established to encourage savings and provide loans to the small and medium scale enterprises and households all over the country. However, the bank's loan approval process were inefficient, thus the level of non-performing loan soared and the bank's asset quality deteriorated, charges on bad and classified loans were high, and profitability was further impaired by rising overhead cost. With all there problems, the financial condition of the banks deteriorated and consequently resulted to insolvency (Oyeyomi, 2003, Anyanwu, 2004).

The scheme involved building self-sustaining community or group of communities and provided financial services, particularly mobilizing deposits and loans to people residing in the locality. Credit facilities were typically granted based on the recognition of the borrower and the availability of a third party guarantor. The first community bank was incorporated in December 1990, and a minimum share capital of \#5 million was needed to obtain a community banking license. The power to regulate and issue provisional license to the community banks was subordinated by Central Bank of Nigeria to the National Board of Community Banks in Nigeria (NBCN). The association successful issued provisional licensees to 1366 community banks between 1990 and 1997. During that period, the Central Bank of Nigeria was responsible for granting final operating license to community banks that had successfully operated for a minimum of two years. Although most of the community bank were able to reach their target market (lower end of the population), performance was weak and a significant number of them were poorly funded (CBN 2002).

Prior to year 2005 the government implemented other poverty reduction developmental initiatives as mentioned earlier. There developmental programmes were established to improve living standards, particularly in the rural areas. However, most of the programmes were poorly organized/administered thereby not achieving the objectives of the programmes.

The theoretical frameworks for this study are economic and psychological theories developed by Kahenman and Tversky (1979); Camerer (1999); Hands (2009) and Andrew (2010). The economic theory argued that the success of any business venture, including microfinance, is determined by the entrepreneurs' ability to deliver appropriate services and profitability. The psychological theory on the other hand argued that a species of profit making private venture that cares about the welfare of its customers can be conceived.

\section{Review of Related Literature}

There have been conflicting ideas about the impact of microfinance in the transformation of rural dwellers in Nigeria by various researchers. Brau \& Woller (2004) noted that the specific impacts of microfinance are hard to pin down and even harder to measure. They suggested that impact assessment require the adoption of research methodologies capable of isolating specific effect out of a complicated web of casual and mediating factors.

Many have subscribed to the believe that microfinance is an effective and powerful tool for poverty reduction. To affirm the above statement, Anien, Rai \& Topai (2003) focus on the ability of micro finance to reach the poor and conclude that microfinance has served people below and above the poverty line. The result of empirical evidence indicates that the poorest can benefit from microfinance from both on economic and social well being point of views, and that this can be done without jeopardizing the financial sustainability of the micro financial institutions (Zainan, 2000; Robin, 2001; Dahiru, 2008; Nwankwo 2007).

The poor can benefit from microfinance. Khandker (1998) in a study "Fighting Poverty Micro credit" using statistical method on assessment on impact of micro finance among three Bangladesh programs, found that every additional 'takas' lend to a woman add additional of 0.18 taka to annual household expenditure.

Ryne \& Holt (1994) noted that the microfinance institution is now a growing phenomenon all over the world. It is emerging as a rapidly growing financial services industry worldwide as a solution to the crippling effects on the conventional banks interest on the poor and those operating micro and small scale enterprises.

In a study conducted by Onyeagocha, Chidebelu, Okorji, Ukoha, Osuji \& Korie (2012) on the determinants of loan repayment of microfinance institutions in South East States in Nigeria using a cross-sectional data and a multi-stage sampling technique. The results of the study revealed that the formal segment was more organized, better equipped with higher quality and well motivated staff than the semi-formal and informal segment. Four microfinance banks were selected as sample size; they are from formal (commercial and development banks), semi-formal (NGO-MFIs and community bank (CB)) and informal (Rotating Savings and Credit Association (ROSCAS), isusu, etc). The study also identify outreach, shocks, training duration, loan size and credit officers experience as the determinants of loan repayment rate in South East States in Nigeria. Taiwo (2012) in another study of the impact of microfinance banks on welfare and poverty alleviation in South West States in Nigeria 
using regression analysis. The study indicates that from the analysis of the data collected from the customers of microfinance banks in Ogun and Lagos States of Nigeria shows that microfinancing has improved the welfare of the enterprises and the individuals in terms of improved savings, earning (both for individual wage earners and the self-employed), facilitated access to loan facilities, improved sales revenue as well as the level of employment and growth in the micro-enterprises examined. The study recommend that since higher education have been found to increase the income of the microfinance institutions (MFIs) clients; the MFIs clients should be encouraged by the microfinance institutions (MFIs) to improve on their current level of education by engaging in adult education or life-long learning $s$ this will have the potency to increase their level of income.

Babajide (2011) studied the effects of microfinancing on micro and small enterprises (SMEs) in South West Nigeria using Diagnostic Test Kaplan-Meier Estimate, Hazard Model and Multiple Regression Analysis. The study indicates that microfinance enhance survival of small business in South West Nigeria; that microfinance does not enhance growth and expansion capacity of MSEs in Nigeria; that microfinance impacts significantly on the level of productivity of MSEs operators in South West Nigeria and that the provision of non-financial service by microfinance institutions enhances the performance of micro and small enterprises (MSEs) in South West Nigeria.

Nguto, Falaye, Elijiah, Agnes, Evans, Olayide and Adama (2013) in a recent study on the analysis and computation of the performance of micro finance banks in Nigeria focusing on standard microfinance bank, Yola. The study employed a standard computer package and chi-square test application. The study shows that, although the portfolio growth of standard microfinance banks Yola is not averagely $50.20 \%$ as claimed by the bank but there is an appreciable growth of $28.96 \%$ in the bank. In another recent study by Godson (2013) on the impact of microfinance on the development of Small Scale Enterprises in the Ledzorkuku Krowor Municipality in the Greater Accra Region of Ghana using descriptive statistics which involve simple percentage, graphical charts and profitability ratio. It was found that there is significant number of the SMEs has the knowledge of the existence of MFIs and some acknowledge positive contributions of MFIs loans towards promoting their growth. The study recommends that microfinance institutions should at all-time give professional advices to SMEs since proper professional advice will inform the lending microfinance institutions whether the amount the SMEs requested for is too much for the project or less.

Finally, Olaitan (2006) observed that microfinance banks have disbursed more than \#800 million micro credits to over 13000 farmers across the country to empower their productive capacities. As such, it is expected that agricultural output will increase with the increase in funding.

\section{Impact of Microfinance on Rural Transformation}

The primary objective of microfinance bank is to ensure that the rural population have access to fund for micro enterprises. This was the reason in the initial stage in Nigeria, it was called community bank and was made to operate in the rural communities. Microfinance has impacted on the rural communities in such a way that it has transformed the economic, social and political life of the people. These transformations include the followings:

-Loans and Advances to Agriculture: The economy of rural communities in Nigeria is agro based, consisting of numerous informal micro economic units. Similarly most informal economic activities in the urban areas are agro-allied. Thus, agriculture and allied economic activities act as sources of livelihood for the poor majority of the people in the urban and rural poor by providing economic opportunities for the production, processing and marketing of agricultural products.

-Investment Opportunities and Viability Options for Micro Finance Bank in the Informal Sector: The informal sector is the source of livelihood for the majority of the population in Nigeria, and the development of the informal sector is thus an imperative for the development of the entire economy. The micro-finance banking scheme can make a significant contribution to the development of the informal economy and consequently to national economic development. Most Micro finance banks have however limited services to the traditional banking function of intermediating between surplus Economic units (SEULS) and Deficit Economic Units (DEUS).

-Savings Mobilization and Credit delivery: Microfinance is close to the rural dwellers, commercial banks find it difficult to establish contact in the rural areas due to insecurity and high overhead cost. Because of these there are a lot of un-bankable population in the rural area that hence there is no financial institution around, their marginal propensity to consume is very high given a percentage of $5 \%$ as the marginal propensity to save (Nwankwo, 2007). But with the advent of modern microfinance in these communities, most rural dwellers have developed the habit of savings, hence microfinance banks now tie any credit advance to compulsory saving. With advent of microfinance bank, such savings now earn interest for the people and encourage savings by the 
rural population.

-Assets Financing: Most microfinance banks help their customers to acquire some needed assets and allow them to pay within a specific period of time. Hair dressers and Barbers need generator for the smooth operation of their business due to the epileptic power supply in Nigeria. Some do not have the finance to get there assets. Some women and men who are into frozen food also need some equipment that they cannot afford due to their limited resources, and some that are into business centers also need some assets to start off. Their assets are computer sets, generators, office equipment and household items. Their microfinance arrange with the suppliers to supply these items to their customers and allow their customers to pay back within a specific period of time.

-Improvement on the Standard of livings: It has been observed that microfinance banks have great impact on the standard of living of the rural dwellers. With the empowerment obtained from these banks in the form of credit and asset acquisition, they were able to set up small businesses which otherwise will translate to financial empowerment. They will be able to take care of their family members. It does not limit to that, hence some will expand their business to the extent of employing more people thereby affecting their standard of living too.

-Provision of Technical and Managerial Assistance to Clients:

Despite the achievement of microfinance banks in transforming the rural areas in Nigeria, they are involved with a lot of challenges which includes the following:

High Operating Cost: This is a situation where the rate on loan is more than the loan and it will affect the level of repayment of the loan.

Repayment Problem: Loan default is major threat to microfinance banks' sustainability; it is the deadly "virus" which afflicts the operation of the banks. It demoralized staff and deprives beneficiaries of further valuable services.

Lack of Experience Credit Officers: Micro financing is more than dispensing loans; to be viable micro finance banks requires experienced and skilled personnel. As a young and growing industry, there is a dearth of experienced staff in planning, product development and effective engagement with customers.

Problem of Illiteracy: The level of illiteracy in the rural areas is high and this affects record keeping and decision making ability of borrowers and consequently affects their relationship with the banks.

Inadequate or non-monitoring of micro and small enterprises by banks thereby leading to default of facilities. The principle of know your customer (KYC) should be applied. Customers should be visited regularly.

Methodology and Analysis

Methodology is therefore concerned with the study of the research methods in a research of this nature.

In this study a $3 \times 2$ (three-by-two) full factorial design is used, which means there are two factors (micro-financing, as independent variable, and rural transformation as dependent variable). The independent factor has 3 levels or values while the dependent factor has 2 levels:

Dependent factor (B) (human financial empowerment) having such factors as:

$\mathrm{B} 1=$ Level of Turnover and B2 = Level of Profit.

Independent factor (A) (Micro financing) having such levels or values as:

$\mathrm{A} 1=$ Level of loan size, $\mathrm{A} 2=$ Interest rate

Pearson Moment Correlation Matrix was used to test for the relationship between microfinance and rural transformation in Ebonyi State as depict below.

Table 1. Person moment correlation matrix

\begin{tabular}{cccc}
\hline Variable & A1 & A2 & B1 \\
\hline A1 & 1 & $0.995^{*}$ & $0.985^{*}$ \\
A2 & $0.985^{*}$ & $0.999^{*}$ & $0.978^{*}$ \\
B1 & $0.975^{*}$ & $0.969^{*}$ & $0.988^{*}$ \\
\hline
\end{tabular}

* Correlation is significant at the 0.05 level (2 tailed). 
The above table explains the correlation coefficients between the dependent variable and the independent variables. The correlation coefficients above do not only show strong positive relationships but are also significantly high. Here the highest coefficient being that of loan size (A1) which is 1 at 0.05 level of significant. The lowest relationship is that of rate of loan repayment (A2) which is 0.985 at 0.05 level of significant.

The table above shows the analysis of the relationships among the dependent and independent variables. Both the independent and the dependent variables showed strong positive relationship in both short and long run.

For the dependent variable, the correlation coefficient (r) between B1 and A1 is 0.985 at 0.05 level of significant. With these high levels of cross sectional relationships that exist among the variables, there is consistency and stability among the variables used in this study.

Test of Hypotheses

As indicated above, the technique of analysis in this research work was the Pearson Product Moment correlation coefficient ( $r$ ). The hypotheses were tested by transforming the correlation coefficient ( $r$ ) into student's-t statistics, using the formula:

$$
\operatorname{tr}=\frac{r N-2}{\sqrt{1-r^{2}}}
$$

Where, tr $=$ Transformed correlation coefficient $(r)$;

$\mathrm{N}=$ No of items;

$\mathrm{N}-2=$ Degree of freedom;

$\mathrm{r}=$ Coefficient of correlation;

$r^{2}=$ Coefficient of determination.

The correlation coefficients above were transformed in testing the hypothesis of this study.

Decision rule: Accept the null hypothesis (Ho) if calculated value is less than the critical value at 0.05 level of significance and 1 degree of freedom; otherwise accept the alternative hypothesis (H1).

\section{Test of Hypothesis One}

Ho: There is no significant relationship between the loan size of microfinance and rural transformation in Ebonyi State.

The hypothesis was tested using tables below.

Table 2. Transformed Person correlation coefficient (r) between size of loan and rural transformation in Ebonyi State B1

\begin{tabular}{lll}
\hline $\mathrm{R} \mathrm{A}_{1} \mathrm{~B}_{1}$ & $\mathrm{R}^{2} \mathrm{~A}_{1} \mathrm{~B}_{1}$ & $\operatorname{Tr}_{1} \mathrm{~B}_{1}$ \\
\hline 0.989 & 0.988 & 18.25 \\
\hline
\end{tabular}

Correlation is significant at the 0.05 level.

Based on the above, the transformed correlation coefficient (tr) calculated value is 18.25 , while the tabulated value of tr at 0.05 level of significance and 1 degree of freedom (df) is 1.514 .

Decision: From the tables above, the t-calculated values of 18.25 is greater than the t-tabulated value of 1.514. The null hypothesis is rejected while the alternative hypothesis is accepted. It is therefore concluded that there is significant relationship between the loan size of microfinance and rural transformation in Ebonyi State.

Test of Hypothesis Two

Ho: There is no significant relationship between interest rate on loan and rural transformation in Ebonyi State.

The table below is used for the hypothesis test. 
Table 3. Transformed Pearson correlation coefficient (tr) between Interest rate on loan (A2) and rural transformation in Ebonyi State (B1)

\begin{tabular}{lll}
\hline $\mathrm{r} \mathrm{A}_{2} \mathrm{~B}_{1}$ & $\mathrm{r}^{2} \mathrm{~A}_{2} \mathrm{~B}_{1}$ & $\operatorname{tr} \mathrm{A}_{2} \mathrm{~B}_{1}$ \\
\hline 0.999 & 0.969 & 7.145 \\
\hline
\end{tabular}

Correlation is significance at 0.05 .

From the table above, the $\mathrm{t}$-calculated value is 7.145 , while the $\mathrm{t}$-tabulated value at 0.05 level of significance and 1 degree of freedom is 1.514 .

Decision rule: From table above, the t-calculated values of is greater than the t-tabulated values at 0.05 level of significance and 1 degree of freedom. Based on this, the null hypothesis is rejected while the alternative hypothesis is accepted with a conclusion that there is significant relationship between interest rate on loan and rural transformation in Ebonyi State.

\section{Conclusion and Recommendations}

In this study, it has been shown through correlation coefficient done above that, microfinance banks have the potentials to transform the rural communities; especially in increasing level of income and reducing vulnerability. It can promote the peoples economic capacity and bring sustainable development.

Despite its potentials to transform the rural and urban poor, microfinance banks in Nigeria are faced, with numerous challenges that need to be addressed.

The following recommendations are made:

Match Products to Customers' Needs: Microfinance banks should develop financial product services and delivery mechanisms that meet the financial needs of a wider spectrum of rural and urban poor.

Examine Cash Flows and Repayment Cycles: More attention to customers preferences in relation to loan size, repayment cycles, flexible loan products and transaction costs in the design of product and delivery mechanisms could further improve program outreach and retention by reducing the risk of borrowing for customers.

Broaden the Range of Products and Services: Microfinance banks (MFBS) should introduce new financial product or services that support customer - defined pathways out of poverty. e.g., improving housing and education for the poor.

Increase Product Flexibility: To help recover from losses associated with unanticipated crises or economic stress events after they occur, microfinance banks should provide more flexible loan and savings products.

Government Regulation: There is need for regulatory authorities (CBN/NDIC) to look into the operation of these microfinance banks by strictly monitoring their activities and ensuring that they are sited where they are meant for, as well as lend to the right people. Possibly, Central Bank of Nigeria (CBN) could set up a fund that microfinance banks could access at a lower rate for onward lending to their customers at a much cheaper rate.

\section{References}

Adamu, G. (2007). Role of Micro finance Institutions in Actualization of MDGS. Paper presented at the induction ceremony of Institute of Chartered Economics of Nigeria (ICEN) in Port Harcourt.

Aliyu, A. (2003). African Rena issuance: Poverty Eradication-The Role of Management. Journal of Management, 39(1), 5-15.

Amin, S., Rai, A. S., \& Topa, G. (2003). Does Microcredit Reach the poor and Vulnerable? Evidence from Northern Bangladesh.

Anyanwa, C. M. (2004). Microfinance Institution in Nigeria: Policy Practice and Potential Central Bank of Nigeria Research paper.

Asian Development Bank. (2000). Finance for the poor: Microfinance Development Strategy.

Babjide, A. (2012). Impact analysis of microfinance banks in Nigeria. International Journal of Economics and Finance, 3(4), 217-223.

Brau, J. C., \& Woller, G. M. (2004). Microfinance, A comprehensive Review of the Existing Literature. Journal of Entrepreneurial Finance and Business Ventures, 9(1), 126-140.

CBN. (2000). Annual report. 
CBN. (2005). Annual report.

Dahiru, M. A., \& Zubair, H. (2008). Microfinance in Nigeria and the prospect of introducing its Islamic version in the light of selected Muslem Countries experience.

Ehigiamusoe, E. O. (2005). Micro Credit; Tool for Poverty Alleviation. A Lead paper Presented at the 12th Annual LAPO Development Forum in Benin City.

Irobi, N. C. (2008). Microfinance and Poverty Alleviation. A case study of Obazu Progressive Women Association Mberi, Nigeria. Uppsala: Department of Economics.

Khander, S. (1998). Fighting Poverty Micro Credit Dhaka. Bangladesh: University Press Ltd.

Khander, S. (2005). Micro-finance and Poverty: Evidence Using Paret Data from Bangladesh World Bank Economic Review.

Ngutor, N., Falaye, A. A., Elijiah, O., Agnes, N., Evans, O. P., Olayide, A., \& Adama, N. V. O. (2013). Analysis and computation of the performance of microfinance banks in Nigeria: A case study of Standard Microfinance Bank, Yola Nigeria. Progress in Applied Mathematics, 5(1), 64-78.

Nwankwo, O. (2007) Micro credit finance and poverty reduction: challenges and prospects. Journal of Banking, Finance and Development, 1(1), 66-70.

Olaitan, M. A. (2006). Finance for small and medium scale Enterprise in Nigeria Journal of international Scale Enterprises in Nigeria. Journal of International Farm Management, 3(2), 7-12.

Onyeagocha, S. U. O., Chidebelu, A. N. D., Okorji, E. C., Ukoha, A. H., Osuji, M. N., \& Korie, O. C. (2012). Determinants of loan repayment of microfinance banks in Southeast of Nigeria. International Journal of Social Sciences and Humanities, 1(1), 4-9.

Oyeyomi, O. E. (2003). An Assessment of Poverty Reduction Strategies in Nigeria (1983-2002). A dissertation submitted in partial fulfillment of the requirement of the award of the doctor of philosophy of the St. Clement University.

Robinson, N. (2001). The microfinance Revolution, sustainable finance for the poor. World Bank Working Paper. Washington, DC.

Ryme, E., \& Holt, S. (1994). Women in Financial and Entrepreneurial Development. Washington DC., Discussion paper 40, World Bank.

Taiwo, J. N. (2012). The impact of microfinance on welfare and poverty alleviation in Southwest Nigeria. Published Ph.D Thesis submitted to the department of Banking and Finance, College of Development Studies, Covenant University, Ota Nigeria, 1-163.

World Bank. (2007). Globalization, Growth and Poverty: Building an Inclusive World Economy. World Bank Policy Research Report. New York: Oxford University press.

\section{Copyrights}

Copyright for this article is retained by the author(s), with first publication rights granted to the journal.

This is an open-access article distributed under the terms and conditions of the Creative Commons Attribution license (http://creativecommons.org/licenses/by/3.0/). 